
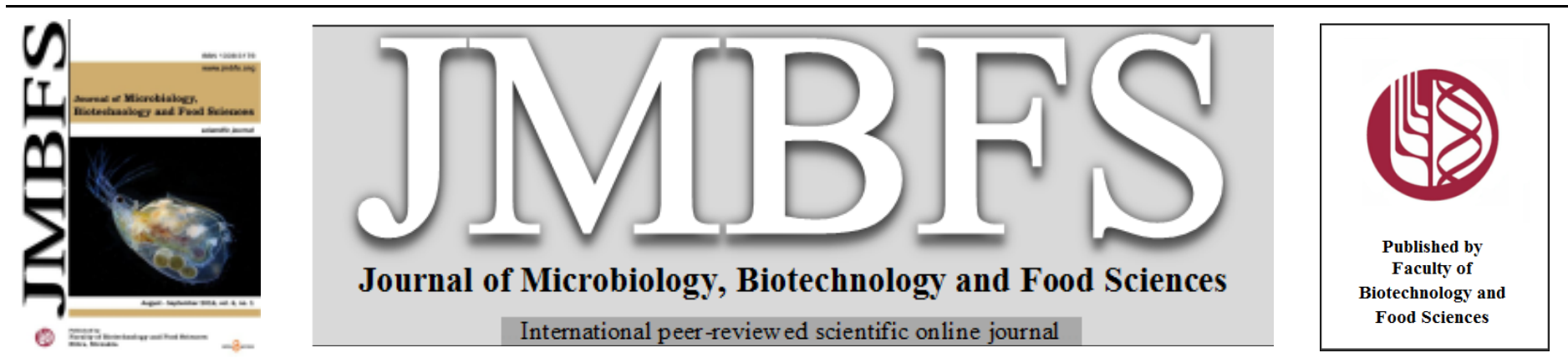

\title{
QUALITY OF CHOK ANAN MANGO AS AFFECTED BY TAPIOCA-SAGO STARCH COATING SOLUTIONS STORED AT ROOM TEMPERATURE
}

\author{
Wong, F.L , Wan Zaliha, W.S. and Yusnita, H.*
}

Address(es):

School of Food Science and Technology, Universiti Malaysia Terengganu, 21030 Kuala Terengganu, Malaysia.

*Corresponding author: yusnita@umt.edu.my

doi: 10.15414/jmbfs.2016.6.1.737-742

\section{ARTICLE INFO}

Received 4.11.2015

Revised 11. 4. 2016

Accepted 28. 4. 2016

Published 1. 8. 2016

Regular article open $\partial_{\text {access }}$

\begin{abstract}
Chok Anan mango, a climacteric fruit, is easily susceptible to quality deterioration during storage. However, no research has been conducted related to the application of tapioca and sago starch coatings on Chok Anan mangoes. Therefore, the aim of this research was to study the effect of tapioca-sago starch coating towards the quality of Chok Anan mango through storage. Hard matures Chok Anan mangoes (stage 2) were coated with different ratios of tapioca (T) and sago starch (S), i.e. $25 \% \mathrm{~T}: 75 \% \mathrm{~S}, 50 \% \mathrm{~T}$ : $50 \% \mathrm{~S}$ and $75 \% \mathrm{~T}$ : $25 \% \mathrm{~S}$. Uncoated mangoes were served as the control. Coated and uncoated Chok Anan mangoes were packed in corrugated box to ripen at ambient temperature $\left(27 \pm 2^{\circ} \mathrm{C}\right)$ for 13 days. Starch analysis demonstrated that sago contained higher amylose $(28.15 \%)$ than tapioca starch and thus a higher percentage of sago starch in the coating solution $(25 \% \mathrm{~T}: 75 \% \mathrm{~S})$ contributed to higher coating's viscosity $(75.90 \mathrm{cP})$. Analysis of coated mangoes exhibited significant better fruit quality as compared to the uncoated samples. Application of starch coating solutions with high percentage of sago starch $(50 \% \mathrm{~T}: 50 \% \mathrm{~S}$ and $25 \% \mathrm{~T}: 75 \% \mathrm{~S})$ were effectively delayed the increased of disease incidence, moisture loss and total soluble solids content as well as delayed the decreased of titratable acidity content during storage. Nevertheless, towards the final day of storage (day 13), no significant difference was shown in the peel color index, firmness and ascorbic acid content of Chok Anan mangoes between all coatings formulations applied.
\end{abstract}

Keywords: Chok Anan mango, quality, sago, tapioca

\section{INTRODUCTION}

Chok Anan mango is one of the mango varieties that gained high demand in Malaysia. However, mango, being a climacteric fruit, is highly perishable and easily susceptible to physiological deterioration after harvest (Baldwin et al. 1999). Normally, the shelf life of mangoes has been just around 4 to 8 days at ambient temperature storage $\left(27 \pm 2^{\circ} \mathrm{C}\right)$ (Jha et al., 2010; Habib et al., 2009) This short shelf life gives rise to extreme difficulties, especially for long distance and export markets. Hence, further investigation is needed to encounter this issue.

One of the effective approaches to extend the shelf life of mango is through the application of edible coatings. Several researches have proved that edible coatings helped to reduce the post-harvest losses by slowing down the mango ripening, hence lead to better preservation of colour, firmness, titratable acidity, total soluble solids and total ascorbic acid contents (Gracia et al., 1998; Dang $\boldsymbol{e t}$ al., 2008; Kittur et al., 2014). Among all the coatings' component choices (polysaccharides, proteins and lipids), starch, which is under the groups of polysaccharides, is the most selective components used in fruits coating (Bibi and Baloch, 2012; Kittur et al, 2001). This is due to its odorless, tasteless, colorless, impermeable to oxygen, biodegradable and safe to be consumed characteristics (Pareta and Edirisinghe, 2006).

Nevertheless, due to the shortage and increasing prices of other starches (wheat, corn and soybeans), tapioca starch is viewed as an alternative source by food companies (FAO, 2004) in fruits' coating (Chiumarelli et al., 2011; Castricin et al., 2012). Tapioca starch is known to have high viscosity (Moorthy, 2004) and clear appearance (William, 2009). However, currently, in Malaysia the total plantation area of tapioca starch has dropped steadily from 20913 ha in 2000 (Tan and Idris, 2000) to 2596 ha in 2011 (Jabatan Pertanian Malaysia, 2013). Thus, starch from sago palm has gained more attention recently as this underutilized palm has been an extremely sustainable plant with the ability to thrive in most soil conditions (Singhal et al, 2008). Despite of having almost the same characteristic with tapioca starch, sago starch is easy to gelatinize, high in viscosity and undergo low syneresis (Takahashi, 1986). Moreover, in 2013, sago has been declared as the "Golden Crop in the $21^{\text {st }}$ Century" (Mahmud, 2013) Several researchers have studied the performance of sago starch in food systems and edible film makings (Karim et al., 2000; Javanmard et al., 2012). However, studies on the performance of coated fruit by using sago starch are still scarce. Owing to the possible potential of sago starch being used as coating ingredients either exclusively or partially with other types of starch, and the lack of published work regarding sago in coating solutions, hence, the effect of different combination of of tapioca-sago starch coating solutions on post-harvest quality of Chok Anan mangoes stored at ambient temperature for 13 days storage were studied.

\section{MATERIAL AND METHODS}

\section{Starch Samples}


size ranged from $13.9-37.6 \mu \mathrm{m}$ ) were purchased from Eugene Chemicals Sdn. Bhd, Malaysia.

\section{Total Amylose Content}

Total amylose content in starch was determined quantitatively based on Hoover and Ratnayake (2001) method. An amount of $5.0 \mathrm{ml}$ of the sample (dissolved starch or amylose standard solution) prepared in were mixed with $5 \mathrm{ml}$ of $\mathrm{I}_{2}-\mathrm{KI}$ solution. Then, the volume was adjusted to $20 \mathrm{ml}$ with distilled water, mixed vigorously and left at room temperature for 15 minutes to allow the development of a blue colour of amylose-iodine complex. Then, the absorbance of the sample was measured using a spectrophotometer (UV Vis-1800, Shimadzu, Japan) at $600 \mathrm{~nm}$ against distilled water as a reference.

\section{Preparation of Coating Solutions}

The coating solutions were prepared according to Gracia et al. (2010) method with slight modification. An amount of $3 \%$ starch powder with different ratios of tapioca (T) to sago (S) starches i.e. F1 (50\% T:50\%S), F2 (75\% T:25\%S) and F3 $(25 \% \mathrm{~T}: 75 \% \mathrm{~S})$ were dissolved in distilled water. The starch mixtures were stirred and heated until $90 \pm 2^{\circ} \mathrm{C}$ and maintained for 3 minutes at this temperature to 
accomplish starch gelatinization. Then, $1 \%(\mathrm{w} / \mathrm{v})$ of palm oil together with $0.5 \%$ $(\mathrm{w} / \mathrm{v})$ of glycerin were added and stirred continuously for 3 minutes, followed by the addition of $0.5 \%(\mathrm{w} / \mathrm{v})$ potassium sorbate for 5 minutes. After that, the coating solutions were homogenized for $10 \mathrm{~min}$ and left it to cool down to room temperature.

\section{Viscosity of Coating Solutions}

The viscosity of tapioca-sago starch coating was measured using a Brookfield digital Viscometer model DV-E (Brookfield engineering labs. INC., Milddleboro, USA) with spindle number 2 at $100 \mathrm{rpm}$. Triplicate readings were taken by immersing the spindle into the coating solutions for 3 minutes to obtain therma equilibrium between solutions and spindle with continued shearing (Al-Hassan and Norizah, 2011). The readings were expressed in centipoises (cP). The viscosity measurement was conducted when the coating solutions reached room temperature $\left(27 \pm 2^{\circ} \mathrm{C}\right)$

\section{Plant Materials}

Hard mature Chok Anan mangoes (13 weeks after flowering) were obtained from Sui Yuan orchard, Kuala Bikam, Perak. Uniform size (250-300g), free from blemish and decay of Chok Anan mangoes were chosen. All the chosen mangoes were at index maturity stage 2 .

\section{Coated Chok Anan Mangoes}

Chok Anan mangoes were washed, sanitized using 200ppm sodium hypochlorite solution for 2 minutes, rinsed and dried prior to coating. Then, Chok Anan mangoes were dipped in the coating solutions for 30 seconds and drip off for 2 min. After that, the coated Chok Anan mangoes were air-dried for 30 minutes at ambient temperature, packed in the corrugated box and stored at ambient temperature $\left(27 \pm 2^{\circ} \mathrm{C}\right)$ for 13 days. Uncoated Chok Anan mangoes were served as the control. All the assessments on coated and uncoated Chok Anan mangoes were carried out for every 2 days of storage interval started on day 1 .

\section{Observation of the Disease Incidence}

Chok Anan mangoes were considered infected when a visible lesion was observed. Visible microbial attacked on the mango was characterized as brown spots and a softening of the injured zone. The degree of disease incidence were assessed according to the percentage of disease area affected per fruit (Khaliq, $\boldsymbol{e}$ al. (2015). The percentage score was then related to a 5-point scale, where $0=$ $0 \%$ area affected, $1=1-5 \%$ area affected, $2=6-15 \%$ area affected (mild), $3=16$ $30 \%$ area affected (moderate) and $4=31-100 \%$ area affected (severe).

\section{Determination of Physiological Weight Loss}

The weight loss percentage of Chok Anan mangoes were calculated as the fresh weight change at each sampling time divided by the initial weight of the mangoes (Mohamed, et al., 2015).

\section{Measurement of the Peel Color Indexes}

The peel color of Chok Anan mangoes measurements i.e. lightness $\left(\mathrm{L}^{*}\right)$, redness $\left(a^{*}\right)$, yellowness $\left(b^{*}\right)$, chroma $\left(C^{*}\right)$ and hue angle $\left(h^{\circ}\right)$ were determined using a Chroma meter (CR 400, Konica Minolta, Japan). Color was measured at each of the two equatorial opposite sides: exposed area and shaded area. Calibration was carried out prior to the determination process (Mohamed, et al., 2015).

\section{Determination of Fruit Firmness}

The firmness of Chok Anan mangoes was measured using a texture analyzer (TA. XTPlus, Stable Micro System Ltd, UK) by measuring the maximum penetration force required. The $\mathrm{P} 2 \mathrm{~N}$ probe was used to penetrate into Chok Anan mangoes at a rate of $5 \mathrm{mms}^{-1}$. The downward distance was set at $10 \mathrm{~mm}$ and automatic return (Rojas-Grau, et al., 2009). Three noses of Chok Anan mangoes for each treatment were taken at three different areas (upper, middle and lower parts) for both sides. The firmness was reported as peak force and expressed in newton per gram of sample.

\section{Determination of Total Soluble Solids (TSS) Content}

TSS was determined according to the AOAC standard method where the analyses were performed with a Milwaukee MA871 digital refractometer with automatic temperature compensation. Edible flesh of Chok Anan mangoes was cut into small cube and the juice was extracted by hand, pressed the flesh in a piece of cheesecloth. Two drops of the mango juice were dropped on the prism of the refractometer. Readings were expressed in ${ }^{\circ}$ Brix.

\section{Determination of Titratable Acidity (TA) Conten}

TA was measured by titration method with $0.1 \mathrm{~N} \mathrm{NaOH}$ and expressed in percent of citric acid $/ 100 \mathrm{ml}$ of juice. Approximately $10 \mathrm{ml}$ of the Chok Anan mangoes were homogenized using blender with $40 \mathrm{ml}$ distilled water and then filtered through cotton wool. Three drops of $0.5 \%$ phenolphthalein were dropped inside the $5 \mathrm{ml}$ of diluted juice solution and titrated using $0.1 \mathrm{~N} \mathrm{NaOH}$ to $\mathrm{pH} 8.2$.

\section{Determination of Total Ascorbic Acid(TAA)}

The determination of the TAA concentration in Chok Anan mangoes was carried out according to the method reported by Khan and Singh (2009). Approximately $5 \mathrm{~g}$ of Chok Anan mango was homogenized in a glass mortar with $25 \mathrm{ml}$ of $6 \%$ metaphosphoric acid containing $0.18 \mathrm{~g}$ of EDTA. The homogenate was centrifuged at $3000 \mathrm{rpm}$ for 15 minutes. The supernatant $(500 \mu \mathrm{L}), 3 \%$ of metaphosphoric acid $(100 \mu \mathrm{L}), 1400 \mu \mathrm{L}$ distilled water and diluted $200 \mu \mathrm{L}$ Folin reagent (Folin: distilled water, 1:5 v/v) were mixed and vortex for 2 minutes Disposable cuvette $(2 \mathrm{ml})$ was used to record the absorbance of the mixed sample after 10 minutes at $760 \mathrm{~nm}$ wavelength using a UV-VIS spectrophotometer. Ascorbic acid concentration was quantified using a standard curve of L-ascorbic acid and was expressed as mg $100^{-1}$ fresh weight.

\section{Statistical Analysis}

A complete randomized design was used and all data were analyzed by using Statistical Analysis System (SAS 9.3, version 16, 2012). The experimental data for coated Chok Anan mangoes were subjected to two-way analysis of variance (ANOVA) (coating solutions treatment $\mathrm{x}$ storage time). LSD was calculated following a significant $(\mathrm{p} \leq 0.05)$ F-test. Data were stated as mean \pm standard error of means.

\section{RESULTS AND DISCUSSION}

Starch Amylose Content

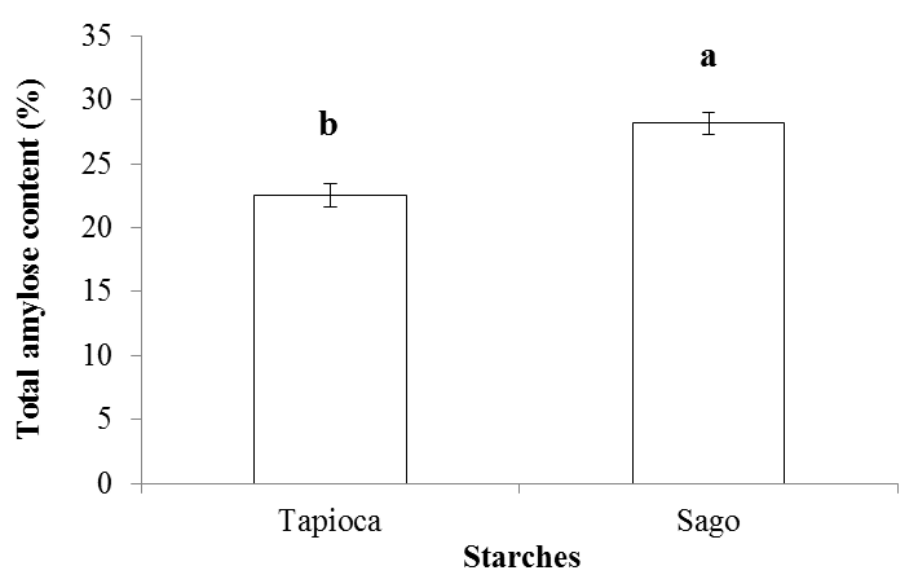

Figure 1 Total amylose content of starches using iodine-binding method. Vertical bars represent standard deviation $(\mathrm{n}=3)$

It is evident that sago starch contained higher amylose content $(28.15 \%)$ as compared to tapioca starch (22.55\%) (Figure 1). As referred to Al-Hassan and Norziah (2012), amylose content in sago starch was found to be in the range of $32-34 \%$. The differences in amylose content in sago starch might probably due to the different parts of the harvested trunk (Singhal et al., 2008). Whereas, the amylose content of tapioca starch was slightly higher than the established value $(17 \%)$ but it is well agreed with the published values of $21.5 \%-22.5 \%$ as reported by several researchers (Chen et al., 2009; Sobolewska-Zielinska and Fortuna, 2010 ).

\section{Coating Solutions Viscosity}

Result showed that, viscosity was significantly higher $(\mathrm{p} \leq 0.05)$ in $25 \% \mathrm{~T}$ : $75 \% \mathrm{~S}$ $(75.90 \mathrm{cP})$ starch coating solutions followed by $50 \% \mathrm{~T}$ : $50 \% \mathrm{~S}(75.33 \mathrm{cP})$ and 75\% T: $25 \% \mathrm{~S}(73.85 \mathrm{cP})$ starch coating solutions measured at ambient temperature $\left(27 \pm 2^{\circ} \mathrm{C}\right)$ (Table 1$)$. 
Table 1 Viscosity of tapioca-sago starch coating solutions measured at $27 \pm 2^{\circ} \mathrm{C}$

\begin{tabular}{lc}
\hline Coating Solutions & Viscosity $\mathbf{( c P )}$ \\
\hline $25 \% \mathrm{~T}: 75 \% \mathrm{~S}$ & $75.93 \pm 0.10^{\mathrm{a}}$ \\
$50 \% \mathrm{~T}: 50 \% \mathrm{~S}$ & $75.33 \pm 0.11^{\mathrm{b}}$ \\
$75 \% \mathrm{~T}: 25 \% \mathrm{~S}$ & $73.85 \pm 0.12^{\mathrm{c}}$ \\
\hline Least significant difference of means at $\mathrm{p} \leq 0.05$ & $0.32^{* * * *}$ \\
level &
\end{tabular}

Mean \pm standard deviation with different letters showed significant difference ( $\leq 0.05$ ) by the least significant difference (LSD) with $n=3$

The result showed that the viscosity of tapioca-sago starch coating solutions increased with the increased of sago starch which might attribute by the higher percentage of amylose contained in its starch composition (Figure 1). This was explained by Xie, et al. (2009) that high amylose content contributed to high viscosity was due to the long linear amylose chains being more easily susceptible to entanglement compared with the inflexibility of the short branched chain in amylopectin.

\section{Disease Incidence}

No significant interaction ( $>0.05$ ) between the storage time and coating formulation was recorded for the disease incidence of Chok Anan mangoes. However, an increment $(\mathrm{p} \leq 0.05)$ for disease incidence of Chok Anan mangoes was shown after seven days of storage (Table 2). This might be associated with the increment of fruit ripening (Khaliq et al., 2015). Meanwhile, regardless of the storage time, disease incidence of Chok Anan mangoes coated with $25 \% \mathrm{~T}$ : $75 \% \mathrm{~S}$ starch solution was significantly lowered as compared to $75 \% \mathrm{~T}$ : $25 \% \mathrm{~S}$ starch solution and control. The mangoes coated with $25 \% \mathrm{~T}$ : $75 \% \mathrm{~S}$ starch solution exhibited the lowest scale $(0.29)$ for the disease incidence parameter (Table 2). This formulation exhibited an approximately $77.52 \%$ inhibition of pathogen development as compared to the control. This might be due to the higher percentage of amylase content in sago starch (Figure 1) which promoted strong cohesive coating properties that can reduce coating porosity (Wittaya, 2012). Thus, preventing the pathogen from entering through the skin surface to fruit tissue, (Yaman \& Bayındırl, 2001) and thereby reduced the disease incidence occurred on mangoes. On the other hand, disease incidence in mangoes coated with $75 \% \mathrm{~T}: 25 \% \mathrm{~S}(0.90)$ starch solution was comparable to control (1.29) and 50\% T: 50\%S starch solution (0.57) (Table 2).

Table 2 Effect of various tapioca-sago starch coating formulations and storage time of the disease incidence of coated Chok Anan mangoes stored at ambient temperature $\left(27 \pm 2^{\circ} \mathrm{C}\right)$

\begin{tabular}{lc}
\hline Factors & Disease Incidence \\
\hline Coating Formulations & \\
$0 \%$ (Control) & $1.29 \pm 0.29^{\mathrm{a}}$ \\
$25 \% \mathrm{~T}: 75 \% \mathrm{~S}$ & $0.29 \pm 0.21^{\mathrm{c}}$ \\
$50 \% \mathrm{~T}: 50 \% \mathrm{~S}$ & $0.57 \pm 0.20^{\mathrm{bc}}$ \\
$75 \% \mathrm{~T}: 25 \% \mathrm{~S}$ & $0.90 \pm 0.10^{\mathrm{b}}$ \\
Storage Time (Days) & \\
1 & \\
3 & $0.00 \pm 0.00^{\mathrm{d}}$ \\
5 & $0.00 \pm 0.00^{\mathrm{d}}$ \\
7 & $0.08 \pm 0.08^{\mathrm{d}}$ \\
9 & $0.67 \pm 0.19^{\mathrm{c}}$ \\
11 & $1.08 \pm 0.23^{\mathrm{bc}}$ \\
13 & $1.42 \pm 0.29^{\mathrm{b}}$ \\
\hline Least significant difference of means at $\mathrm{p} \leq 0.05$ levels \\
Coating Formulations (F) \\
Storage Time (S) & $0.08 \pm 0.36^{\mathrm{a}}$ \\
$\mathrm{F} \times \mathrm{S}$ & $0.49^{*}$ \\
\hline
\end{tabular}

Mean \pm standard error of means followed by the different letters within the same factors denote a significant difference $(\mathrm{p} \leq 0.05)$ by the least significant difference $(\mathrm{LSD})$ with $\mathrm{n}=6$. $*=$ significant at $\mathrm{p} \leq 0.05$

\section{Physiological weight loss}

There was an interaction between the storage time and coating formulation $(\mathrm{p} \leq 0.05)$ for the physiological weight loss of Chok Anan mangoes. It is notable that the physiological weight loss of all coated and uncoated Chok Anan mangoes increased significantly $(\mathrm{p} \leq 0.05)$ towards the 13 days of storage (Figure 2$)$. This was further explained by Khaliq et al (2015) where the fruit weight loss during storage might be attributed by the loss of water during transpiration and respiration process on mangoes.



Storage Time (Days)

Figure 2 Physiological weight loss of Chok Anan mangoes as influenced by the storage time time and different formulations of tapioca-sago starch coating solutions towards 13 days of storage at ambient temperature $\left(27 \pm 2^{\circ} \mathrm{C}\right) . n=9(3$ fruits $\times 3$ replications). Vertical bars represent the standard error of means and are invisible when the values are smaller than the symbol. $\operatorname{LSD}(\mathrm{P} \leq 0.05): \mathrm{F}=0.50$, $\mathrm{S}=0.49, \mathrm{~F} \times \mathrm{S}=\mathrm{NS}$

Starting from day 5 until day 13 of storages, Chok Anan mangoes coated with 25\% T: $75 \% \mathrm{~S}$ and $50 \% \mathrm{~T}: 50 \% \mathrm{~S}$ starch solutions showed the lowest percentage of fruit weight loss $(p \leq 0.05)$ compared to the control and mangoes coated with 75\% T: 25\% S starch solutions. However, Chok Anan mangoes coated with $75 \% \mathrm{~T}$ : $25 \% \mathrm{~S}$ starch solutions started to show a significant effect of physiological weight loss $(p \leq 0.05)$ with control after 11 days of storage, whereby the control sample obtained the highest percentage of fruit weight loss. This might be ascribed to the higher amylose content $(28.15 \%)$ and viscosity of coating solutions $(75.90 \mathrm{cP})$ which contained higher composition of sago starch. Higher amylose content in starch was responsible for the formation of coherent and effective strong coating (Rindlav-westling et al., 1998), while higher viscosity of solutions provided a great thickness of coatings as well as strong adhesion to the peel surface, hence lowered the water vapor permeability. This was similar to the research done by Hernandezmunoz et al., (2008) who reported coating solution in $1.5 \%$ Chitosan resulted in greater viscosity and thickness of coating, further reducing moisture loss.

\section{Peel Color Indexes}

There was a significant interaction $(\mathrm{p} \leq 0.05)$ between the storage time and coating formulation for the pale color of Chok Anan mangoes stored at ambient temperature. Figure 5 showed that all the color indexes (except hue angle) of Chok Anan mangoes increased as storage time increased. A significant difference $(p \leq 0$. 05) was shown between coated and uncoated Chok Anan mangoes for all the peel color indexes. Starting from day 9 until day 13 storages, the $L^{*}$ of peel color value for uncoated mangoes increased significantly $(p \leq 0.05)$ in comparison with coated mangoes (Figure 3a). Besides, the peel color values of control, including redness $\left(\mathrm{a}^{*}\right)$, yellowness $\left(\mathrm{b}^{*}\right)$ and Chroma increased $(\mathrm{p} \leq 0$. 05 ) with the decreased of $h^{0}$ after 9 days of storage as compared to coated samples.

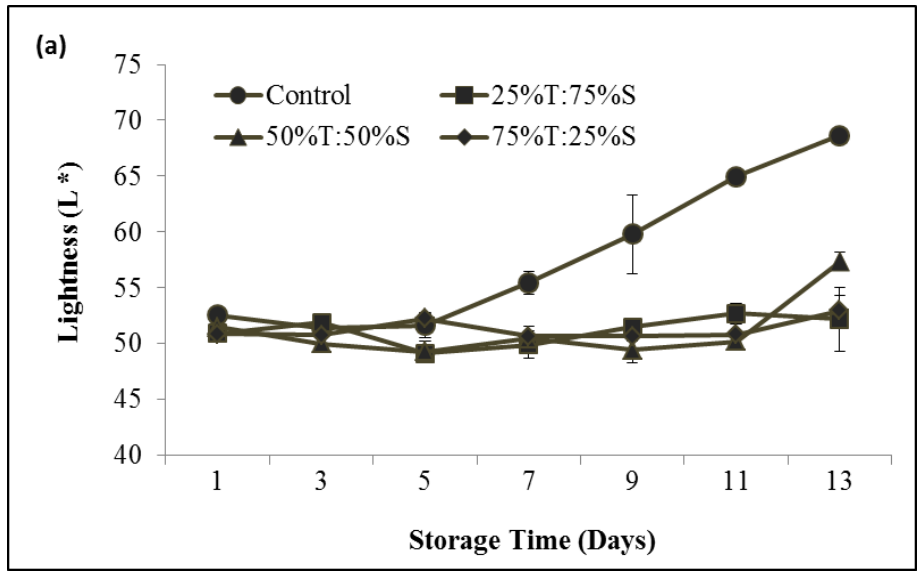





Figure 3 Color indexes of L* (a), a* (b) b* (c), hue (d) and Chroma (e) values of the peel of Chok Anan mangoes as influenced by the storage time and different formulation of tapioca-sago starch solutions stored at ambient temperature $\left(27 \pm 2^{\circ} \mathrm{C}\right) . \quad \mathrm{n}=9$ (3 fruits $\times 3$ replications). Vertical bars represent the standard error of means and are invisible when the values are smaller than the symbol. $\operatorname{LSD}(\mathrm{P} \leq 0.05): \mathrm{L}^{*}, \mathrm{~F}=1.31, \mathrm{~S}=1.73, \mathrm{~F} \times \mathrm{S}=3.45 ; \mathrm{a}^{*}, \mathrm{~F}=3.80, \mathrm{~S}=1.90, \mathrm{~F} \times$
$\mathrm{S}=7.27 ; \mathrm{b}^{*}, \mathrm{~F}=2.03, \mathrm{~S}=2.69, \mathrm{~F} \times \mathrm{S}=5.38 ; \mathrm{b}^{*}, \mathrm{~F}=2.03, \mathrm{~S}=2.69, \mathrm{~F} \times \mathrm{S}=$ $5.38 ; \mathrm{C}^{*}, \mathrm{~F}=1.80, \mathrm{~S}=2.38, \mathrm{~F} \times \mathrm{S}=4.76, \mathrm{~h}^{\circ}, \mathrm{F}=2.12, \mathrm{~S}=2.80, \mathrm{~F} \times \mathrm{S}=5.60$

The increased in $\mathrm{L}^{*}$ value with the decreased of $\mathrm{h}^{\circ}$ as storage time increased indicated that mangoes were lighter in color due to the development of yellowish colour in the peel mangoes. Whereas, the increased of Chroma value revealed that the peel mangoes shifted from a dull to a more vivid yellow/red colour (Nunes et al., 2007). Similar result was presented by Nunes et al. (2007), where the $\mathrm{L}^{*}$ and Chroma values of 'Tommy Atkins' mangoes increased while $\mathrm{h}^{\circ}$ decreased during storage. Surprisingly, all the coated mangoes maintained the peel color indexes throughout the 13 days of storage and no significant difference ( $>0.05)$ was reported among coated samples. This indicated that coatings maintained the mango fruits natural color characteristic. This can be described as starch coatings provided a layer to fruit surface to reduce the gas permeability (Pagella et al., 2002) and thus delayed the respiration rate of mangoes and prolonged the shelf life. With the delayed of the ripening process, conversion of organic acids to sugars were declined (Wills et al., 2007a), and hence, the degradation of chlorophyll and synthesis of carotenoids was inhibited (CarriloLopez et al., 2000).

\section{Fruit Firmness}

Significant interaction (storage time $\mathrm{x}$ coating formulation) were found in the firmness of Chok Anan mangoes stored at ambient temperature. It is clear from the results that the firmness of all coated and uncoated Chok Anan mangoes decreased as storage time prolonged (Figure 4). This was due to the substantia transformation and solubilisation of cell wall polymers such as cellulose, hemicellulose and pectin, which causes wall loosening and disintegration, resulting in fruits softening (Zaharah \& Singh, 2011). A significant difference $(\mathrm{p} \leq 0.05)$ was observed between coated and uncoated Chok Anan mangoes was reported after 9 days of storage. The starch coatings exerted a beneficial effect on mangoes' firmness in which, at the end of the storage periods (Days 13), al the coated samples were high in their firmness values as compared to control mangoes. However, between different formulations of coated mangoes, no significant difference $(p>0.05)$ was observed (Figure 4$)$. The application of mango coatings played a role in inhibiting the fruit softening during storage. This was due to the ability of the coating which functions to enclose the pores on the fruit surface (Ali et $\boldsymbol{a l}$., 2011) hence created a good barrier against gas transmission. With the lack of oxygen supply to the fruit, the respiration rate of fruits and the activity of enzyme hydrolysis were decreased; therefore, the softening of fruits can be delayed (Dang et al., 2008). In addition, the slower decrement of physiological weight loss in coated Chok Anan mangoes as discussed in section 3.4 also contributed to the delayed of fruit softening as water loss from was retarded and shriveling symptoms was reduced.

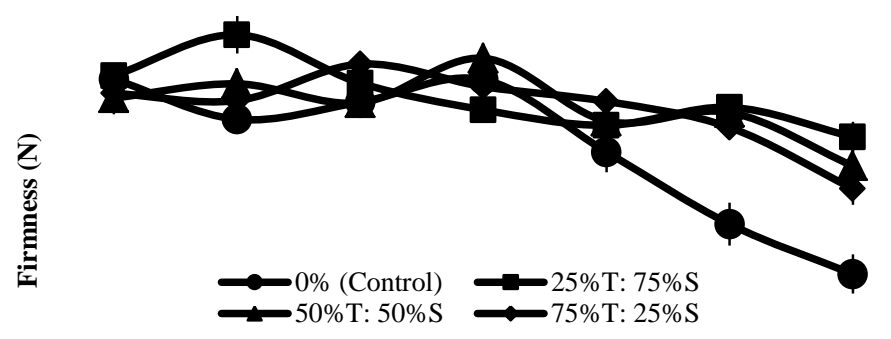

Storage Time (Days)

Figure 4 Fruit firmness of Chok Anan mangoes as influenced by the storage time and different formulation of tapioca-sago starch solutions stored at ambient temperature $\left(27 \pm 2^{\circ} \mathrm{C}\right) . n=9$ ( 3 fruit $\times 3$ replications). Vertical bars represent the standard error of means and are invisible when the values are smaller than the symbol. $\operatorname{LSD}(\mathrm{P} \leq 0.05): \mathrm{F}=\mathrm{ns}, \mathrm{S}=\mathrm{ns}, \mathrm{F} \times \mathrm{S}=\mathrm{ns}$. $\mathrm{ns}=$ non-significant

\section{Total Soluble Solids Content (TSS)}

The TSS content of Chok Anan mangoes significantly interacted between the storage time and starch coating formulations. A significant increased $(\mathrm{p} \leq 0.05)$ was observed in control mangoes after five days of storage, whereas mangoes coated with $50 \% \mathrm{~T}$ : $50 \% \mathrm{~S}$ and $75 \% \mathrm{~T}$ : $25 \% \mathrm{~S}$ starch solutions, showed an increment after day seven. The most delayed increment in TSS value was mangoes coated with $25 \% \mathrm{~T}$ : $75 \% \mathrm{~S}$ starch solution. Chok Anan mangoes coated with this formulation only showed significant increase in TSS after 11 days of storage (Figure 5). The increased of TSS content with prolonged storage time indicated that the mangoes undergone ripening process in which pectin substances starch or other polysaccharide were converted into soluble sugar (Eskin et al., 2013). Whereas, mango coated with higher percentage of sago 
starch seemed to delay the transformation of polysaccharide into soluble sugar. This might be highly related to its higher viscosity property in higher percentage of sago starch (Table 1) which is believed to provide strong adhesion on the fruit surface and could reduce the porosity of the coating. This characteristic, thus, created a barrier that reduced the oxygen interchangeable on the fruit surface (Khaliq et al., 2015) and hence inhibited the respiration rate as well as lowered the conversion of starch into sugar (Ali et al., 2011).
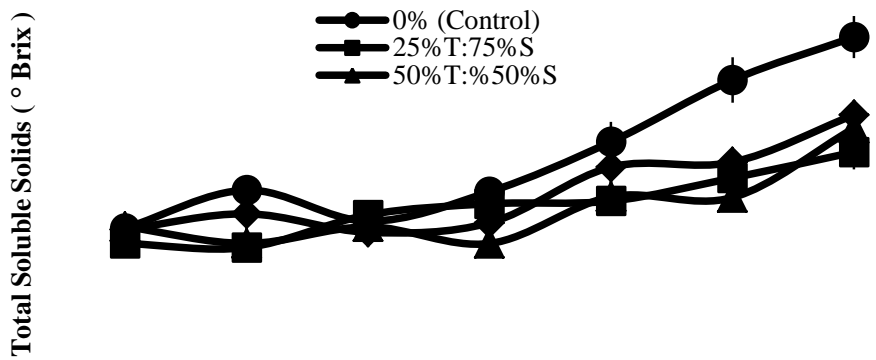

Storage Times (Days)

Figure 5 Total soluble solids (TSS) content of Chok Anan mangoes as influenced by the storage time and different formulation of tapioca-sago starch solutions stored at ambient temperature $\left(27 \pm 2^{\circ} \mathrm{C}\right) . \mathrm{n}=9$ (3 fruits $\times 3$ replications). Vertical bars represent the standard error of means and are invisible when the values are smaller than the symbol. $\mathrm{LSD}(\mathrm{P} \leq 0.05)$ : $\mathrm{F}=0.45, \mathrm{~S}=0.59, \mathrm{~F} \times \mathrm{S}=1.18$.

\section{Titratable Acidity (TA)}

It was notable that a significant interaction was shown between the storage time and coating formulation on the TA content of Chok Anan mangoes (Figure 6). The decreased of acidity content during storage might probably due to the conversion of starch into sugar and further utilizing the organic acid for respiratory metabolism ( Pauziah et al., 2014; Khaliq et al., 2015 ). Uncoated mangoes and coated with $75 \% \mathrm{~T}$ : $25 \% \mathrm{~S}$ starch solution showed significan decreased of TA $(\mathrm{p} \leq 0.05)$ after seven days of storage, while the other two samples $(50 \% \mathrm{~T}: 50 \% \mathrm{~S} ; 25 \% \mathrm{~T}: 75 \% \mathrm{~S})$ decreased after nine days of storage Whereas, Chok Anan mangoes coated with $25 \% \mathrm{~T}$ : $75 \% \mathrm{~S}$ starch solutions showed significantly higher TA as compared to sample coated with $75 \% \mathrm{~T}: 25 \% \mathrm{~S}$ and control after nine days of storage. Again, no differences $(p>0.05)$ in TA were observed for mangoes coated with more than or equal to $50 \%$ of sago starch (50\% T: $50 \% \mathrm{~S}$ and $25 \% \mathrm{~T}: 75 \% \mathrm{~S})$. This showed that starch coatings provided a protective oxygen barrier to the fruits, hence reduced the respiration rate and thus delayed the decrement of acidity content (Ali et al., 2011)

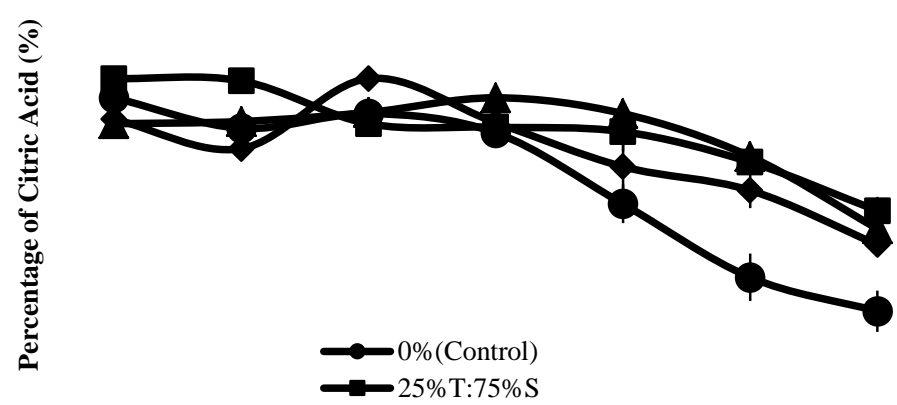

Storage Times (Days)

Figure 6 Titratable acidity (TA) content of Chok Anan mangoes as influenced by the storage time and different formulation of tapioca-sago starch solutions stored at ambient temperature $\left(27 \pm 2^{\circ} \mathrm{C}\right) . \mathrm{n}=9$ (3 fruits $\times 3$ replications $)$. Vertical bars represent the standard error of means and are invisible when the values are smaller than the symbol. LSD $(\mathrm{P} \leq 0.05) ; \mathrm{F}: 0.05, \mathrm{~S}: 0.07, \mathrm{~F} \times \mathrm{S}=0.13$

\section{Total Ascorbic Acid Content (TAA)}

Both factors, i.e. storage time and coating formulation showed a significant interaction for the TAA content of Chok Anan mangoes at ambient temperature storage. As shown in Figure 7, the percentage of TAA content on coated and uncoated Chok Anan mangoes decreased gradually as storage time increased. The TAA content of uncoated Chok Anan mangoes started to decrease significantly after nine days of storage and showed the lowest $(\mathrm{p} \leq 0.05)$ TAA content as compared to coated Chok Anan mangoes. This might due to the presence of oxygen at surrounding during storage, which increased in respiration rate, thus, resulted in the release of water. This, thereby increased the degradation of ascorbic acid as ascorbic acid is readily oxidized in the presence of moisture (Ottaway, 2010).

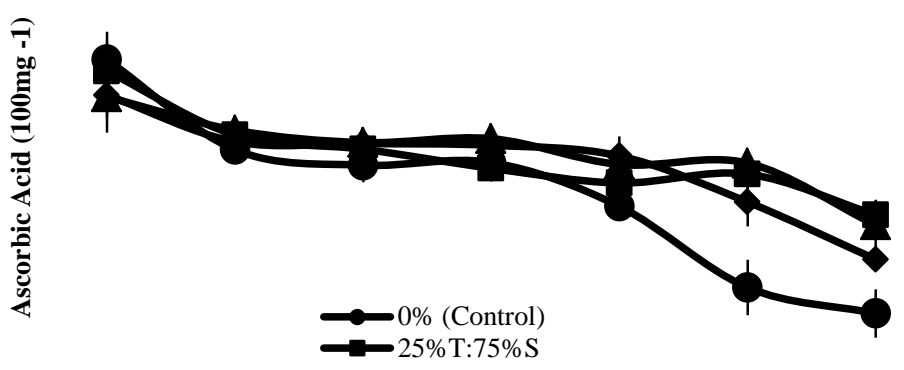

Storage Time (Days)

Figure 7 Total ascorbic acid (TAA) content of Chok Anan mangoes as influenced by the storage time and different formulation of tapioca-sago starch coating solutions stored at ambient temperature $\left(27 \pm 2^{\circ} \mathrm{C}\right) . \quad \mathrm{n}=9$ (3 fruits $\times 3$ replications). Vertical bars represent the standard error of means. LSD $(\mathrm{P} \leq 0.05)$ $\mathrm{F}=0.58, \mathrm{~S}=0.77, \mathrm{~F} \times \mathrm{S}=1.54$

However, sample coated with $25 \% \mathrm{~T}$ : $75 \% \mathrm{~S}$ starch solutions retained $(\mathrm{p}>0.05)$ the TAA content throughout the storage periods. Surprisingly, no significant difference $(p>0.05)$ was observed between the coated Chok Anan mangoes until the last days of assessments (Days 13). This might attribute by the function of starch coating, which lowered the oxygen penetration into the fruit tissue, hence delayed the respiration rate. In this sense, the oxidations of ascorbic acid to dehydroascorbic acid were also decreased (Yaman \& Bayoundurl, 2002)

\section{CONCLUSION}

This study proved that all tapioca-sago coating formulations prolonged the storage life of Chok Anan mangoes by delaying the yellow peel color development and activity of fruit softening as well as slowing down the decrement of the ascorbic acid content as compared to uncoated sample throughout the 13 days of storage. On top of this, mangoes coated with $50 \% \mathrm{~T}$ : $50 \% \mathrm{~S}$ and $25 \% \mathrm{~T}: 75 \% \mathrm{~S}$ starch solutions were more effective in delaying the ripening process by inhibiting the pathogen development, retarding the fruit weight loss as well as slowing down the changes of soluble solids and acidity content at the end of storage (day 13). Hence, it can be concluded that mangoes coated with more than or equal to $50 \%$ of sago starch $(50 \% \mathrm{~T}$ : $50 \% \mathrm{~S}$ and $25 \% \mathrm{~T}$ : $75 \% \mathrm{~S}$ ) maintained the quality and prolonged the mango shelf life effectively.

\section{REFERENCES}

Al-Hassan, A.A. \& Norziah, M.H. 2012. Starch-gelatin edible films: Water vapor permeability and mechanical properties as affected by plasticizers. Food Hydrocolloids, 26(1), 108-117. http://dx.doi.org/10.1016/j.foodhyd.2011.04.015 Ali, A., Muhammad, M.T.M., Sijam, K. \& Siddiqui, Y. 2011. Effect of chitosan coatings on the physicochemical characteristics of Eksotika II papaya (Carica papaya L.) fruit during cold storage. Food Chemistry, 124, 620-626. http://dx.doi.org/10.1016/j.foodchem.2010.06.085

Baldwin, E.A., Burns, J.K., Kazokas, W., Brecht, J., Hagenmaier, R., Bender, R. \& Pesis, E. 1999. Effect of two edible coatings with different permeability characteristics on mango (Mangifera indica L.) ripening during storage. Postharvest Biology and Technology, 17(3), 215-226. http://dx.doi.org/10.1016/s0925-5214(99)00053-8

Bibi, F.\& Baloch, M. K. 2012. Postharvest quality and shelf life of mango (Mangifera indica L.) fruit as affected by various coatings. Journal of Food Processing and Preservation 38(1): 499-507. http://dx.doi.org/10.1111/j.17454549.2012.00800.x

Castricini, A., Coneglian, R. \& Deliza, R. 2012. Starch edible coating of papaya: effect on sensory characteristics. Ciencia e Tecnologia. Alimentos, 32(1), 84-92. http://dx.doi.org/10.1590/s0101-20612012005000016

Chen, C. H., Kuo, W. S. \& Lai, L.S. 2009. Effect of surfactants on water barrier and physical properties of tapioca starch/decolorized hsian-tsao leaf gum films. Food Hydrocolloids, 23(3), 714-721. http://dx.doi.org/10.1016/j.foodhyd.2008.06.006

Chiumarelli, M., Ferrari, C. C., Sarantópoulos, C. I. G. L. \& Hubinger, M. D 2011. Fresh cut "Tommy Atkins" mango pre-treated with citric acid and coated 
with cassava (Manihot esculenta Crantz) starch or sodium alginate. Innovative Food Science \& Emerging Technologies, 12(3), 381-387. http://dx.doi.org/10.1016/j.ifset.2011.02.006

Dang, K. T. H., Singh, Z. \& Swinny, E. E. 2008. Edible coatings influence fruit ripening, quality, and aroma biosynthesis in mango fruit. Journal of Agricultural and Food Chemistry, 56(4), 1361-70. http://dx.doi.org/10.1021/jf072208a

Eskin, N. A. M., Hoehn, E. \& Shahidi, F. 2013. Fruits and vegetables. In Biochemistry of foods, N.A.M. Eskin \& F. Shahidi (eds), pp 49-126, san Diego:Academic Press.

FAO. 2004. Global cassava market study business opportunities for the use of cassava. Proceedings of the Validation forum on the Global Cassava Development Strategy, Italy: International Fund for Agricultural Development.

Garcia, M., Martino, M. \& Zaritzky, N. 1998. Plasticized starch-based coatings to improve strawberry (Fragaria $\times$ ananassa) quality and stability. Journal of Agricultural and Food Chemistry, 46, 3758-3767. http://dx.doi.org/10.1021/jf980014c

Garcia, L. C., Pereira, L. M., Sarantópoulos, C. I. G. D. L. \& Hubinger, M. D. 2010. Selection of an edible starch coating for minimally processed strawberry. Food and Bioprocess Technology, 3(6): 834-842. http://dx.doi.org/10.1007/s11947-009-0313-9

Habib, A. R., Tariq, M., Shehla, S. And Saima, M. 2009. Effect of Polyethylene Packaging and Coating Having Fungicide, Ethylene Absorbent and Antiripening Agent on the Overall Physico-Chemical Composition of Chaunsa White Variety of Mango at Ambient Temperature During Storage. Pakistan Journal of Nutrition, 8 (9): 1356-1362. http://dx.doi.org/10.3923/pjn.2009.1356.1362

Hernandez-Munoz, P., Almenar, E., Valle, V., Velez, D. \& Gavara, R. 2008. Effect of chitosan coating combined with postharvest calcium treatment on strawberry (Fragaria $\times$ ananassa) quality during refrigerated storage. Food Chemistry, 110(2), 428-435. http://dx.doi.org/10.1016/j.foodchem.2008.02.020

Hoover, R. 2001. Composition, molecular structure, and physicochemical properties of tuber and root starches: a review. Carbohydrate Polymers, 45, 253 267. http://dx.doi.org/10.1016/s0144-8617(00)00260-5

Jabatan Pertanian Semenajung Malaysia. 2013. Maklumat tanaman. In Booklet Statistik Tanaman (sub sektor tanaman makanan) ed. Unit Perangkaan Bahagian Perancangan, Teknologi Maklumat dan Komunikasi, pp 8. Kuala Lumpur: Unit Perangkaan Bahagian Perancangan. Teknologi Maklumat dan Komunikasi.

Javanmard, M., Chin, N.L., Yusof, Y.A. \& Endan, J. 2012. Application of sago starch as a gelling agent in jam. Journal of Food,10(4), 275-286. http:// dx.doi.org/10.1080/19476337.2011.653693

Jha, S. K., Sethi, S., Srivastav, M., Dubey, A. K., Sharma, R. R., Samuel, D. V. K. and Singh, A. K. 2010. Firmness characteristics of mango hybrids under ambient storage. Journal of Food Engineering 97(2): 208-212. http://dx.doi.org/10.1016/j.jfoodeng.2009.10.011

Karim, A. A., Norziah, M. H. \& Seow, C. C. 2000. Methods for the study of starch retrogradation. Food Chemistry, 71, 9-36. http://dx.doi.org/10.1016/s0308-8146(00)00130-8

Khaliq, G., Muda Mohamed, M. T., Ali, A., Ding, P. \& Ghazali, H. M. 2015 Effect of gum arabic coating combined with calcium chloride on physicochemical and qualitative properties of mango (Mangifera indica L.) fruit during low temperature storage. Scientia Horticulturae, 190, 187-194. http://dx.doi.org/10.1016/j.scienta.2015.04.020

Khan, A. S. \& Singh, Z. 2009. 1-MCP application suppresses ethylene biosynthesis and retards fruit softening during cold storage of 'Tegan Blue' Japanese plum. Plant Science, 176(4), 539-544 http://dx.doi.org/10.1016/j.plantsci.2009.01.012

Kittur, F., Saroja, N., Habibunnisa \& Tharanathan, R. 2001. Polysaccharidebased composite coating formulations for shelf-life extension of fresh banana and mango. European Food Research and Technology, 213, 306-311. http://dx.doi.org/10.1007/s002170100363

Mahmud, A. T. 2013. Jabu: More focus on sago industry in $11^{\text {th }}$ Malaysia plan. The Star Online. http://www.thestar.com.my/News/Community/2013/11/17/JabuMore-focus-on-sago-industry-in-11th-Malaysia-Plan/. Accessed on 7 May 2014.

Mohamed, C., Jessica, P., Didier, M., Gérard, L. \& Marie, N. D. 2015. Preservation of mango quality by using functional chitosan-lactoperoxidase systems caotings. Postharvest Biology and Technology, 101, 10-14. http: //dx.doi.org/10.1016/j.postharvbio.2014.11.003.

Moorthy, S. 2004. Tropical sources of starch. In Starch in Food: Structure Function and Applications, A. Eliasson (ed), pp 321-259, England: Woodhead Publishing.

Nunes, M., Emond, J. \& Brecht, J. 2007. Quality curves for mango fruit (cv. Tommy Atkins and Palmer) stored at chilling and nonchilling temperatures. Journal of of Food Quality 30: 104-120. http://dx.doi.org/10.1111/j.17454557.2007.00109.x

Ottaway, P. B. 2010. Stability of vitamins during food processing and storage. In L. H. Skibsted, J. Risbo \& M. L. Andersen (eds), Chemical Deterioration and Physical Instability of Food And Beverages 539-560p New Delhi: Woodhead Publishing.

Pagella, C., Spigno, G. \& Faveri, D. De. 2002. Characterization of starch based edible coatings. Food and Bioproducts Processing, 80, 193-198. http://dx.doi.org/10.1205/096030802760309214
Pareta, R. \& Edirisinghe, M. 2006. A novel method for the preparation of starch films and coatings. Carbohydrate Polymers, 63(3), 425-431. http://dx.doi.org/10.1016/j.carbpol.2005.09.018

Pauziah, M. \& Wan Mohd Reza Ikwan, W. H. 2014. Effects of 1methylcyclopropene on quality of Chokanan mangoes stored at ambient. Journal of Tropical Agriculture and Food Science, 42(1), 37-49. http://ejtafs.mardi.gov.my/jtafs/42-1/Chokanan\%20mangoes.pdf

Rindlav-westling, A., Stadingb, M., Hermansson, A. \& Gatenholma, P. 1998 Structure, mechanical and barrier properties of amylose and amylopectin films Carbohydrate Polymers, 36, 217-224. http://dx.doi.org/10.1016/s0144 $\underline{8617(98) 00025-3}$

Rojas-Graü, M. A., Soliva-Fortuny, R. \& Martín-Belloso, O. 2009. Edible coatings to incorporate active ingredients to fresh-cut fruits: A review. Trends in Food Science \& Technology, 20(10), 438-447. http://dx.doi.org/10.1016/j.tifs.2009.05.002

Saxena, D. C. 2013. Sago starch : characterization, modification and utilization for food and non-food applications, (p2) India.

Singhal, R. S., Kennedy, J. F., Gopalakrishnan, S. M., Kaczmarek, A., Knill, C. J. \& Akmar, P. F. 2008. Industrial production, processing, and utilization of sago palm-derived products. Carbohydrate Polymers, 72(1), 1-20. http://dx.doi.org/10.1016/j.carbpol.2007.07.043

Sobolewska-Zielinska, J and Fortuna, T. 2010. Retrogradation of starches and maltodextrins of origin various. Scientiarum Polonorum Acta, 9(1), 71-81. jm/2012.indexcopernicus.com/fulltxt.php? ICID=906843

Tan, S. and Idris, K. 2000. Present situtaion and future potential of cassava in Malaysia. Proceedings of the Sixth Regional Workshop, eds R. H. Howeler and Tan. S. L, pp 102-109, Vietnam: CIAT

William, R. M. 2009. Starch Use in Foods. In N.B., James \& L. W. Roy (Eds), Starch: Chemistry and Technology 770p. $3^{\text {rd }}$ edition. USA: Academic Press.

Wills, R., McGlasson, B., Graham, D. and Joyce, D. 2007. Physiology and Biochemistry. In R. Wills (Ed), Postharvest: An Introduction to the Physiology and Handling of Fruit, Vegetables and Ornamentals 28-51p. UK: UNSW Press.

Wittaya, T. 2012. Rice starch-based biodegradable films: properties enhancement. In A. A., Eissa (Ed), Structure and Function of Food Engineering (p 103-134). Croatia: InTech.

Xie, F., Yu, L., Su, B., Liu, P., Wang, J., Liu, H. \& Chen, L. 2009. Rheological properties of starches with different amylose/amylopectin ratios. Journal of Cereal Science, 49(3), 371-377. http://dx.doi.org/10.1016/j.jcs.2009.01.002 Yaman, O. \& Bayındırlı, L. 2001. Effects of an edible coating, fungicide and cold storage on microbial spoilage of cherries. European Food Research and Technology, 213, 53-55. http://dx.doi.org/10.1007/s002170100334

Yaman, Ö. \& Bayoundurl, L. 2002. Effects of an edible coating and cold storage on shelf-life and quality of cherries. LWT - Food Science and Technology, 35(2), 146-150. http://dx.doi.org/10.1006/fstl.2001.0827

Zaharah, S. \& Singh, Z. 2011. Mode of action of nitric oxide in inhibiting ethylene biosynthesis and fruit softening during ripening and cool storage of 'Kensington Pride' mango. Postharvest Biology and Technology, 62, 258-266. http://dx.doi.org/10.1016/j.postharvbio.2011.06.007 